\title{
Research on Deviations of China's Fiscal Competition among Local Governments from the Tiebout Model
}

\author{
Wang Lijuan \\ School of Public Finance, Taxation and Public Administration, Jiangxi University of Finance and \\ Economics, Nanchang, P.R. China, 330013 \\ (Email:helenjufe@ hotmail.com)
}

\begin{abstract}
There're essential differences of economic and social system between China and the western developed countries which decides the model of fiscal competition would be different. In this paper, a comparative method is adopted to find the deviations of China's fiscal competition from the classic Tiebout model. These deviations include the aim of fiscal competition deviating from the utility maximization of local residents, the competitor deviating from a fully-authorized fiscal government and the precondition deviating from free population mobility. Thus some suggestions are put forward to help improve China's fiscal competition by correcting the competitive aim, developing fiscal autonomy, hardening the soft budget and reforming the Hukou policy.
\end{abstract}

Keywords: Local Government Fiscal Competition Tiebout Model Deviation

\section{Introduction}

Fiscal decentralization reform has been widely made in the world since 1980s although the exact initiation behind it varied. In developed countries, this reform was argued to help reorganize an efficient service government while in developing countries it was aimed to stimulate economic growth and in some transitional countries it was regarded as an imperative result of economic system reform. As a consequence, the local governments became increasingly independent, especially in financial terms. Thus, to maximize each financial utility, they would compete for the mobile factors with each other. Of that, fiscal competition means the local government tries to attract the mobile factors with the strategy of tax or expenditure policy.

Many literatures focused on fiscal competition among local governments in developed countries and its economic effects after Tiebout's original paper in 1956. New topic in this field was to testify the extent of fiscal competition reaction by employing spatial econometric models. To some extent, study on fiscal competition among China's local government was comparatively late since the fiscal decentralization hadn't been implemented until 1980. Literatures on fiscal competition among China's local governments could be traced to Zhong Xiaomin who classified the 30 provinces into four groups according to their patterns of expenditure level and tax burden in 2004. By analyzing the population mobility among these four groups it showed that fiscal competition did exist among China's local government and some developed provinces has shifted to the expenditure strategy while less developed provinces mostly took the tax strategy. Yang Zhiyong pointed out there were some uncommon strategies of fiscal competition in China after comparing the practices between of China and those of the abroad, like land preference policy. There are some empirical literatures as well employing spatial econometric models to testify the fiscal competition and its reaction extent among China's local governments. The current literatures usually borrowed the model developed in the western developed countries to analyze the practices in China. However, little literature pays attention to the different background with which China's fiscal competition among local governments was developed and its deviation from the classic Tiebout model developed in the western countries. 


\section{An ideal Tiebout model}

Tiebout set a classic fiscal competition model in his fundamental paper in 1956. In his model, there were supposedly enough districts with different pattern of public expenditure and tax burden. Tax was assumed only to be from the local residents' income. Population could mobile freely among the different districts for their favorite combination of public expenditure and tax burden. Due to the fixed land size or level of other factors, there would be an optimum number of residents for each district theoretically. To attract the population, every district would maximize the representative resident's utility by providing more public goods with less tax revenue until the optimum size would be achieved. By doing this, the fiscal competition among local governments would help achieve the efficient provision of public goods like that of private goods in the private markets among the competing firms.

There many approaches to the Tiebout model. In this paper, we'll explore three important characters of it and examine their counterparts in China. The first is the government's utility function which decides the aim of fiscal competition. Though Tiebout criticized the expenditure side of Samuelson's was just depicted of a typical voter's, he still implied the government acted to achieve the maximized utility of representative resident in his following analysis. Secondly, each district would fully decide their pattern of expenditure and tax. There would no federal or central government who can influence them. Thirdly, consumers-voters could fully mobile among different districts to match their preferences with patterns of expenditure and tax mostly. If they didn't like the pattern of some district, they could vote with feet.

\section{The deviations of China's practices from the ideal model}

There are essential differences of political and economic system between China and the western developed countries which will necessarily cause some unique characters of China's fiscal competition among local governments.

\subsection{China's practices of fiscal decentralization and tax-sharing system}

Five tiers of overlapping governments compose the administrative system in China. There are 32 provinces in the mainland which govern about more than 800 administrative cities which are the second and third tiers. The fourth tier consists of around 1500 counties. The lowest tier includes thousands of administrative villages. Since 1980, various forms of fiscal decentralization have been explored in China between the central government and the local governments. The current fiscal system is tax-sharing system which states all kinds of tax revenues into three groups, namely owned by the local governments, the central governments and shared by two levels of governments. Moreover, the authority of imposing and adjusting taxes is excludably confined to the central government while the local governments have nothing to do with it.

\subsection{Deviation from the utility maximization of the residents}

Although fiscal competition among China's local governments is aimed to attract the production factors as well, the utility of local governments don't always meet that of local residents. Since the head governor is usually appointed by the upper-level government commission instead of being elected by local residents, he or she is mainly supposed to be responsible for the performance examining system (PES) which is made by the upper-level government. Under the background of head governor responsibility, the utility of local governments is therefore inclined to meet the PES demand.

Mostly, the PES is composed of GDP and fiscal revenue indicators. Thus the utility of local governments would be to pursue the economic growth instead of the utility of local residents. Ping Xinqiao \& Bai Jie observed that local governments would think some expenditure items high and others low due to their different impact on the economic growth. That explains the phenomenon in China that local governments always compete for investment solicitation with each other while couldn't fully fund educational, medical service or social security.

\subsection{Deviation from fiscal autonomy and hard budget}

If local governments have fully fiscal autonomy, they can adjust the tax burden to achieve a better pattern of expenditure and tax when competing with the others. And a hard 
budget constraint would help to reflect a transparent pattern to consumers-voters. However, the local governments in China have little authority to impose tax or even adjust the tax rate. The local government is more like the subdivisions of the central government than a fiscally independent authority. Moreover, the budgets of local governments are rather soft. According to National Bureau of Statistics of China, the off-budget revenue is 641.46 billion RMB which accounts for $9.3 \%$ of total national revenues. And more than $90 \%$ of off-budget revenue is contributed by the local governments. Usually, the on-budget expenditure programs will be rather strictly supervised while those off-budget ones are less supervised.

Thus, at least two shortcomings appear as a result. Firstly, since the local governments couldn't adjust the tax, they would pursue other hidden tax preferences to compete with each other. Even land preference policy has widely been adopted to attract investment. Secondly, local governments are more inclined to collect off-budget revenues, like land revenues, to achieve a better pattern due to the soft budget. These would make the fiscal competition more hidden and their patterns of expenditure and tax are becoming obscure for consumers-voters.

\subsection{Deviation from full mobility}

In Tiebout model an imperative hypothesis is fully mobility. Votes with feet would make local governments feel pressured to tailor their patterns of expenditure and tax to consumers-voters' preferences. However, in China, there has been a Hukou policy aiming to regulate population mobility among different districts. Only having Hukou in a district, couldn't the residents consume public goods provided in this district. These public goods include public schools, medical security and social security etc. Hukou policy impairs the population mobility to the developed provinces, especially the biggest metropolitan where advanced educational and medical services are provided. To get a Hukou in these provinces, usually the new entrants are supposed to accomplish higher education and buy a new house or apartment with size above the ruled one. On the one hand, the developed provinces have usually been winners in fiscal competition due to the abundant revenue compared to the less developed provinces. On the other hand, by issuing Hukou to the new entrants, they could easily attract the new residents abundant in capital and human capital. Thus the less developed provinces get worse due to Hukou policy.

\section{Conclusions}

There are a few imperative hypotheses in Tiebout model functioning to achieve efficiency. If these constraints are loosened in reality, like practices of China's fiscal competition among local governments, it would turn out to deviate efficiency. Suggestions are therefore put forward to correct these deviations as followings:

First of all, the PES for local governments needs reviewing and modifying. Under the background that the head governor is appointed by the upper-level government, the PES should mostly cover indicators composing residents utility like educational, medical and social secure services. In the long run, changing the appointment of the head governor to being elected by the local residents is obviously more vital.

Secondly, the local governments should be authorized more administrative rights of revenue and the budget constraint should be hardened. By doing that, local governments are more entitled to adjust their patterns of expenditure and tax to local residents' preferences.

Thirdly, it's necessary to loosen Hukou policy. Full mobility is vital to achieve votes with feet which could help residents meet their preferences to different governments' patterns at the most.

The last not the least is to improve the fiscal transfer system. Fiscal competition helps to achieve resources allocation efficiency. However, a perfect fiscal transfer system could achieve equity by guaranteeing the losers in fiscal competition are affordable to provide qualified public goods to local residents.

\section{References}

[1] Brueckner and Saavedra, "Do Local Governments Engage in Strategic Property-tax Competition?," National Tax Journal, 54(2), pp.203-229, 2001.

[2] Case, A. C., H. S. Rosen and J. R. Hines, "Budget Spillovers and Fiscal Policy Interdependence: Evidence from the 
States," Journal of Public Economics, 52(3), pp.285-307, 1993.

[3] Guo Qingwang and Jia Junxue, "Strategy Interaction among Local governments, Fiscal Expenditure Competition and Regional Economic Growth," Management World, (10), pp.17-27, 2009. (In Chinese)

[4] Heyndels Bruno and Jef Vuchelen, "Tax Mimicking among Belgian Municipalities," National Tax Journal, 51(1), pp.89-101, 1998.

[5] Keen, Michael and Maurice Marchand, "Fiscal Competition and the Pattern of Public Spending," Journal of Public Economics, 66(1), pp.33-53, 1997.

[6] Li Tao and Zhou Ye'an, "Study on Fiscal Expenditure Competition among Local Governments-Evidence from China's Provinces," Management World, (2), pp.12-22, 2009.(In Chinese)

[7] Ping Xinqiao and Bai Jie, "China's Fiscal Decentralization and Local Provision of Public Goods," Finance and Trade Economics, (2), pp.47-55, 2006. (In Chinese)

[8] Shao Jun, "Testing Spatial Spillover of Fiscal Expenditure," South China Journal of Economics, (9), 3-11, 2007. (In Chinese)

[9] Shen Kunrong and $\mathrm{Fu}$ Wenlin, "Tax Competition, Region Gambling and Economic Growth," Economic Research Journal, (6), pp.16-26, 2006.(In Chinese)

[10] Tiebout, Charles M., "A Pure Theory of Local Expenditures," The Journal of Political Economy, 64(5), pp.416-424, 1956.

[11] Wang Lijuan, "Population Mobility and Fiscal Competition--a Comparative Study on Fiscal Zone and Hukou Policy," Journal of Central University of Finance \& Economics, (3), pp.17-21, 2010. (In Chinese)

[12] Wildasin, David E., "Nash Equilibria in Models of Fiscal Competition," Journal of Public Economics, 35(2), pp.229-240, 1988.

[13] Wilson, John D., "A Theory of Interregional Tax Competition," Journal of Urban Economics, 19 (3), pp.296-315, 1986.

[14] Wilson, John Douglas and David E.Wildasin, "Captial Tax Competition: Bane or Boon," Journal of Public Economics, 88 (6), pp.1065-1091, 2004.

[15] Yang Zhiyong, "Comparative Analysis of China's Fiscal Competition among Local Governments and That of Abroad," Economic Issues in China, (6), pp. 61-65, 2005. (In Chinese)

[16] Zhao Zhiyun and Guo Qingwang, "On the Extent of China's Fiscal Decentralization," International Tax in China, (11), pp.9-13, 2005. (In Chinese)

[17] Zhong Xiaomin, "Fiscal Competition among China's Local Governments in the Market-Oriented Reform," Journal of Finance and Economics, (1), pp.21-30, 2004. (In Chinese)

[18] Zodrow, George R. and Peter Mieszkowski, "Pigou, Tiebout, Property Taxation and the Underprovision of Local Public Goods," Journal of Urban Economics, 19(3), pp.356-370, 1986. 